Acta vet. scand. $1978,19,166-178$.

From the FAO/WHO Collaborating Centre for Animal Mycoplasmas, Institute of Medical Microbiology, University of Aarhus, Denmark.

\title{
BOVINE MYCOPLASMAS: CLASSIFICATION OF GROUPS RELATED TO MYCOPLASMA MYCOIDES*
}

\author{
By \\ Gerd Askaa, H. Ern $\varnothing$ and M.O.Ojo*
}

\begin{abstract}
ASKAA, G., H. ERN $\emptyset$ and M. O. OJO: Bovine mycoplasmas: Classification of groups related to Mycoplasma mycoides. Acta vet. scand. 1978, 19, 166-178. - Mycoplasmas which had in various ways proved to be related to Mycoplasma mycoides were studied with a view to classification and nomenclature. Representative strains of $M$. mycoides - subspecies mycoides (PG1) and subspecies capri (PG3) - and of the as yet unclassified bovine serogroups 7 (PG50) and L (B144P) were compared serologically and by DNA-DNA hybridization. The serological methods used (metabolism inhibition, growth inhibition and immunofluorescence) are usually considered to be species-specific.

(1) The two subspecies of M. mycoides can be clearly separated by all three serological methods, whereas the hybridization studies revealed great similarity between them, the relatedness value being 0.70 .
\end{abstract}

(2) The two serogroups (7 and L) cross-reacted with each other in all three serological tests, and their relatedness value was 0.83 . The relatedness value between group 7 and $M$. mycoides subsp. mycoides was found to be 0.72 , and only limited cross-reactions were demonstrated by immunofluorescence and growth inhíbition.

(3) Although groups 7 and L were found only to a slight degree to be genetically related to M. bovigenitalium with a DNA homology of $20 \%$ or less, a serological cross-reaction between group 7 and $\mathrm{M}$. bovigenitalium has been demonstrated by growth inhibition in previous studies.

Conclusions drawn on the basis of the premises just mentioned give rise to a dilemma, because three different situations exist. In (1), significant serological differences were disclosed, but the DNA homology was great. In (2), the serogroups 7 and L showed conformity between hybridization and serological findings, whereas, in (3), hy-

* This work was supported by a grant from the Danish Medical Research Council.

** Holder of a Danish State Scholarship. Present address: the Department of Veterinary Microbiology and Parasitology, University of Ibadan, Ibadan, Nigeria. 
bridization showed a distinct separation, but a serological cross-reaction does occur. If the results of hybridization are regarded as decisive, the two subspecies of $M$. mycoides can be preserved, but this is at variance with the general perception that the serological methods used here are species-specific. If, on the other hand, the serological results are chosen to be decisive, PG1 and PG3 must be regarded as two separate species, and consequently Group L/7 may also be a separate species.

As regards the relation between group $L / 7$ and $M$. bovigenitalium, the results of hybridization clearly show that they are two different species. As a consequence of this, it must be accepted that crossreactions may occur - also in growth inhibition - between different species which, genetically, are even far removed from each other.

On account of the fundamental nature of these problems, the authors prefer to leave the decisions - also as to the nomenclature - to the Subcommittee on the Taxonomy of Mycoplasmatales.

mycoplasmas; classification; M. mycoides-related g rou p s

The classification of mycoplasmas causing contagious pleuropneumonia in cattle and goats into two subspecies, M. mycoides subsp.mycoides and M. mycoides subsp.capri (Freundt 1955), respectively, has repeatedly been discussed. This classification was first suggested by Edward (1953) on the basis of cultural and biochemical similarities and the sharing of common complement-fixing antigens in the two groups of organisms. Edward also pointed to the close resemblance between the pathology of contagious pleuropneumonia in cattle and goats. The existence of common antigens between these two groups was further demonstrated by the use of agglutination, double immunodiffusion, and growth precipitation (Cottew et al. 1969, Ern $\phi \&$ Jurmanoví 1973). Immunofluorescence, metabolism-inhibition and growthinhibition tests (Al-Aubaidi et al. 1972, Cottew et al., Ern $\phi \&$ Jurmanová, Ern $\phi$ et al. 1973) did not, on the other hand, reveal any serological relationship. The electrophoretic patterns of these and other mycoplasma strains were compared by Razin (1968). It was found that the patterns of a group of caprine strains, including PG3, the type strain of M. mycoides subsp. capri, were closely related to that of the type strain of $M$. mycoides subsp. mycoides, PG1.

Serological relationship between strain $\mathrm{Y}$-goat, isolated from a goat with peritonitis, and the bovine organism, M. mycoides subsp. mycoides, was noted by Laws (1956), and confirmed by Cottew \& Lloyd (1965) as well as by Al-Aubaidi et al. The latter investigators examined a large number of bovine, caprine and ovine strains that were compared by metabolism-inhibition and 
growth-inhibition tests. The study revealed that 25 cultures of goat mycoplasmas related to $\mathrm{Y}$-goat were serologically indistinguishable from each other and from bovine strains of M. mycoides subsp. mycoides. The Y-goat group did not show any relationship in the metabolism-inhibition and growth-inhibition tests to organisms belonging to M. mycoides subsp. capri. It was concluded that all 25 goat mycoplasmas related to $\mathrm{Y}$-goat should be classified as $\mathrm{M}$. mycoides subsp. mycoides with strain $\mathrm{Y}$-goat as the representative of the caprine/ovine strains of this subspecies.

Another taxonomical question is the classification of serogroup 7 of Leach (1973) and serogroup L of Al-Aubaidi \& Fabricant $(1971 \mathrm{a}, \mathrm{b})$. These groups have been extensively studied, but not finally classified. Al-Aubaidi \& Fabricant (1971a,b) did not find cross-reactions between group 7 and group L using metabolism-inhibition and growth-inhibition tests, while Ern $\phi \& J u r$ manová observed one-way cross-reactions by the same methods. The latter investigators demonstrated antigenic relatedness to the M. mycoides group, but it was decided to await the results of nucleic acid experiments and further serological studies before proposing a final classification. The studies should include representative strains of group 7 and group L (PG50 and B144P), both type strains of M. mycoides (PG1 and PG3), and a representative strain of $\mathrm{M}$. bovigenitalium. The last-mentioned species was included because Cottew (1970) and Ern $\phi$ \& Jurmanová found significant cross-reactions in growth inhibition between M. bovigenitalium and group 7. Whereas Cottew on the basis of this fact suggested that group 7 be regarded as a subdivision of M. bovigenitalium, Ern $\phi \&$ Jurmanová felt inclined to relate the group to $\mathrm{M}$. mycoides.

The purpose of the present work was to study, by means of "species-specific" serological methods and nucleic acid hybridization, the following problems:

1. Should the present classification of PG1 and PG3 into two subspecies of M. mycoides be maintained, or should they rather be assigned to two different species?

2. Do PG50 and B144P represent the same subspecies, two different subspecies within the same species, or two different species?

3. Is group 7 a subspecies of M. mycoides or of M. bovigenitalium or a separate species? 


\section{MATERIALS AND METHODS}

\section{Organisms, media and growth conditions}

The type strains of M. mycoides subsp. mycoides and M. mycoides subsp. capri, PG1 and PG3, and the representative strain of serogroup 7 of Leach, PG50, were supplied by D. G. ff. Edward. The representative strain of group $\mathrm{L}, \mathrm{Al}$-Aubaidi and Fabricant, B144P, was received from $J$. Fabricant. The representative strain of $M$. bovigenitalium (K) was isolated from a bull with a spontaneous mycoplasma infection in the vesicular gland (Blom \& Ern $\phi$ 1967). This strain was preferred to the type strain PG11 because of its better growth in liquid medium.

For DNA preparation, the mycoplasmas were grown in 51 of Bacto Heart Infusion Broth (Difco) supplemented with $16 \%$ of horse serum, $8 \%$ of a $25 \%$ fresh yeast extract, $0.008 \%$ of thallium acetate, and penicillin ( 400 i. u. per $\mathrm{ml}$ ). Labelled DNA was produced by growing mycoplasmas in liquid medium containing $1.0 \mu \mathrm{Ci}$ per $\mathrm{ml}$ of thymidine-methyl- ${ }^{3} \mathrm{H}$ (New England Nuclear, 6.7 $\mathrm{Ci}$ per mmole). The cultures were incubated aerobically at $37^{\circ} \mathrm{C}$.

\section{Serological examinations}

The methods used were the metabolism-inhibition test, the growth-inhibition test and the indirect epi-immunofluorescence technique as described by Ern $\phi$ et al. (1973), Ern $\phi \&$ Jurmanová (1973) and Rosendal \& Black (1972), respectively. In addition to crude rabbit antisera, globulin fractions of hyperimmune antisera were used in some cases. The globulin fractions were obtained by precipitation in $50 \%$ saturated ammonium sulphate.

\section{Isolation of DNA}

Cells were collected from broth in the Sorvall continuous-flow system at $48000 \times \mathrm{g}$ and a flow rate of $20 \mathrm{ml}$ per min. The DNA was isolated by the method of Marmur (1961). By this method the cells are lysed with sodium dodecyl sulphate, and the released DNA is deproteinized by the use of sodium perchlorate and chloroform-isoamyl alcohol. RNA was digested with a mixture of $0.1 \mathrm{mg}$ of ribonuclease (Sigma, bovine pancreas) and $25 \mathrm{u}$ of ribonuclease-T ${ }_{1}$ (Calbiochem, B-grade) per $\mathrm{ml}$ of DNA solution. Finally, the DNA was precipitated with isopropanol and treated with pronase (Calbiochem), $0.25 \mathrm{mg}$ per $\mathrm{ml}$ of DNA solution. 
Before use, the pronase was self-digested at $37^{\circ} \mathrm{C}$ for $2 \mathrm{hrs}$. At least two preparations of DNA were isolated from each strain. The DNA preparations were examined by the scanning curve and the extinction rise of DNA in $1 \times \mathrm{SSC}(0.15 \mathrm{M}-\mathrm{NaCl}$ and $0.015 \mathrm{M}$ trisodium citrate) under controlled temperature increase. All DNA preparations used had an $\mathrm{OD}_{260} / \mathrm{OD}_{280}$ ratio of more than 1.8, and the hyperchromicity shift during the thermal melting was more than $40 \%$. The melting point and the corresponding GC content (Marmur \& Doty 1962) was hereby determined and served as an additional control. The analyses were made in a Beckmann Acta CIII spectrophotometer equipped with a Beckmann temperature controller and an $\mathrm{X}-\mathrm{Y}$ recorder.

\section{DNA-DNA hybridization}

The hybridization experiments were carried out as described by Denhardt (1966). The method is a membrane-filter technique, where unlabelled, single-stranded DNAs from the organisms to be compared are fixed to a number of nitrocellulose membranefilters. The DNA-loaded filters are then incubated in a solution of single-stranded ${ }^{3} \mathrm{H}$-labelled DNA. Non-specific sticking of single-stranded labelled DNA is prevented by pre-incubation of the filters in an albumin solution.

The yield of radioactivity bound to the filters was measured in a liquid scintillation counter (Packard 3320) using a toluenebased scintillation fluid. Relative homologies were calculated as percentage binding in heterologous reactions relative to that of the homologous reaction. Relatedness values were calculated as the ratio of the product of the heterologous DNA-DNA reaction yields to the product of the homologous yields in the reciprocal reactions between two nucleic acids (Table 4 ).

The results of the hybridization experiments were analysed statistically using the two-way variance analysis of Alling (1967).

\section{RESULTS}

The results of the serological studies are shown in Table 1. PG1 and PG3, the type strains of M. mycoides subsp. mycoides and M. mycoides subsp. capri, gave distinct positive results in the homologous reactions, whereas no heterologous reactions were observed between these strains.

Strain Y-goat gave distinct reactions with PG1 in all tests. 


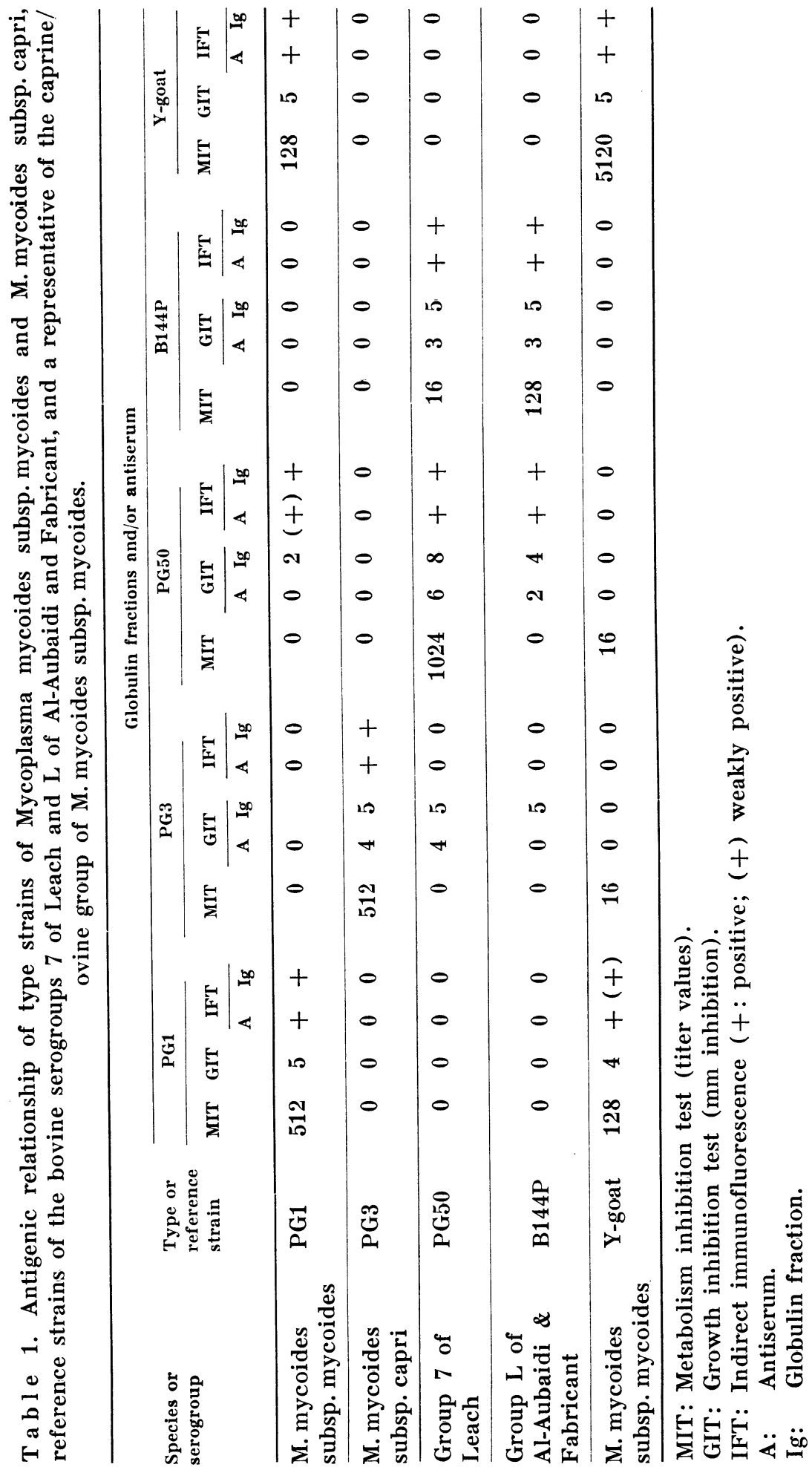


Y-goat was further inhibited in the metabolism-inhibition test to a very low degree by sera against PG3 and PG50, whereas PG1 reacted with the globulin fraction from PG50 antiserum in the growth-inhibition and immunofluorescence tests. Only a weak cross-reaction was noted in immunofluorescence using crude antiserum.

PG50 and B144P, the reference strains of bovine serogroups 7 and L, cross-reacted in the growth-inhibition test as well as in immunofluorescence, whereas only a one-way cross-reaction appeared in the metabolism-inhibition test. Growth of PG50 and B144P was inhibited by the globulin fraction from PG3 serum, and PG50 was further inhibited by antiserum against PG3.

The content of guanine plus cytosine of DNA from PG1, Ygoat, PG3, PG50 and B144P was 27.1\%, 26.3\%, 24.4\%, $25.4 \%$ and $25.4 \%$, respectively, and that of strain $\mathrm{K}$ was measured as $29.3 \%$.

T a b l e 2. DNA-DNA hybridization of the type strains of M. mycoides subsp. mycoides and M. mycoides subsp. capri (PG1 and PG3); reference strains of serogrups 7 of Leach and $L$ of Al-Aubaidi \& Fabricant (PG50 and B144P); reference strains of the caprine/ovine group of M. mycoides subsp. mycoides and M. bovigenitalium (Y-goat and K).

\begin{tabular}{|c|c|c|c|c|c|c|c|}
\hline \multirow{2}{*}{$\begin{array}{l}{ }^{3} \mathrm{H}-\text { labelled } \\
\text { DNA from }\end{array}$} & \multirow{2}{*}{$\begin{array}{l}\text { Number } \\
\text { of experi- } \\
\text { ments }\end{array}$} & \multicolumn{6}{|c|}{ Hybridization $(\%)^{\star}$} \\
\hline & & PG1 & PG3 & PG50 & B144P & Y-goat & $\mathbf{K}$ \\
\hline PG1 & 2 & 100 & $75 \pm 10$ & $84 \pm 1$ & $79 \pm 10$ & & $23 \pm 10$ \\
\hline PG3 & 7 & $93 \pm 13$ & 100 & $66 \pm 9$ & $69 \pm 11$ & $94 \pm 6$ & $13 \pm 6$ \\
\hline PG50 & 7 & $86 \pm 21$ & $83 \pm 9$ & 100 & $94 \pm 11$ & $93 \pm 23$ & $13 \pm 11$ \\
\hline B144P & 4 & $90 \pm 12$ & $89 \pm 11$ & $88 \pm 18$ & 100 & & $20 \pm 14$ \\
\hline
\end{tabular}

* The results are given as average values of a number of individual experiments \pm standard deviation.

Results of the DNA hybridization experiments are listed in Tables 2, 3 and 4 .

The mutual reactions in the hybridization experiments between DNA from PG1 and PG3 were $75 \%$ and $93 \%$, respectively (Table 2). The relatedness value was from this calculated to be 0.70 (Table 3 ).

Between strains PG1 and Y-goat homologies of $88 \%$ and $93 \%$ were found; the relatedness value calculated was 0.82 (Table 4). 
T a b l e 3. Relatedness values* of the strains PG1, PG3, PG50 and $\mathrm{B} 144 \mathrm{P}$.

\begin{tabular}{lccc}
\hline & PG3 & PG50 & B144P \\
\hline PG1 & 0.70 & 0.72 & 0.71 \\
PG3 & & 0.55 & 0.61 \\
PG50 & & & 0.83 \\
\hline
\end{tabular}

* The relatedness values are calculated according to Alling (1967, using geometrical means, and also according to the formula given in Table 4, using arithmetical means. The relatedness value for $\mathrm{PG50/B144P}$ is indistinguishable from 1.00 on the $95 \%$ level.

The homologies between strains PG50 and B144P were $94 \%$ and $88 \%$, giving a relatedness value of 0.83 . Reactions between PG1 and PG50/B144P were between $79 \%$ and $93 \%$ with relatedness values of 0.72 and 0.71 , and those between PG3 and PG50/B144P were between $66 \%$ and $89 \%$ with relatedness values of 0.55 and 0.61 (Table 3 ).

DNA from strain $\mathrm{K}$ was found to be related to strains PG1, PG3, PG50 and B144P with $23 \%, 13 \%, 13 \%$ and $20 \%$ (Table $2)$; in these cases the reciprocal reactions were not carried out and the relatedness values therefore not calculated.

T a b l e 4. DNA-DNA hybridization of PG1 and Y-goat of M. mycoides subsp. mycoides.

\begin{tabular}{lrr}
\hline \multirow{2}{*}{${ }^{3}$ H-labelled DNA } & \multicolumn{2}{c}{ Hybridization $(\%)$} \\
& \multicolumn{2}{c}{ M. mycoides subsp. mycoides } \\
\cline { 2 - 3 } & PG1 & Y-goat \\
\hline PG1 & 100 & 93 \\
Y-goat & 88 & 100 \\
\hline
\end{tabular}

$$
\text { Relatedness value }=\frac{0.93 \times 0.88}{1 \times 1}=0.82
$$

\section{DISCUSSION}

A generally accepted definition of the species concept does not exist. This, of course, impedes any attempt to classify organisms representing transitions between taxa already established.

The Subcommittee on the Taxonomy of Mycoplasmatales (1971) has emphasized "that a separation of a group of organ- 
isms in two or more species should be based on a variety of distinctive properties and that the results of growth inhibition, gel electrophoresis and nucleic acid hybridization studies should be considered in particular'. In line with this recommendation, the Subcommittee (1975) decided to await the results of the nucleic acid hybridization and gel electrophoresis studies as well as further serological comparisons before issuing a recommendation on the taxonomic status of the M. mycoides group.

The hybridization experiments presented in this study are, as appears from Table 3, somewhat unstable, but the statistical analysis demonstrated that the relatedness values are indicative of a high relationship among the organisms of the M. mycoides group, and the mutual arrangement among the relatedness values are in accordance with results of serological investigations.

The GC content of the DNA of PG1 and PG3 was found to be $27.1 \%$ and $24.4 \%$, respectively, but the difference of approx. $3 \%$ does not exclude a high degree of homology between the deoxyribonucleic acids. The level of hybridization of about $80 \%$ with the relatedness value of 0.70 would not seem to exclude that PG1 and PG3 should be classified within the same species. In the present study as well as in several previous publications by different authors (Cottew et al. 1969, Al-Aubaidi et al. 1972, Ernф \& Jurmanová 1973, Ernф et al.), PG1 and PG3 were found to be unrelated in immunofluorescence, metabolism-inhibition and growth-inhibition tests. However, common antigens were demonstrated by complement fixation, agglutination, double immunodiffusion, and growth precipitation (Edward 1953, Cottew et al. 1969, Ern $\varnothing$ \& Jurmanová 1973). The close relationship is further supported by the examination of several wild strains, which react with antisera against both PG1 and PG3, also in growthinhibition and immunofluorescence tests (Ern $\phi$, unpublished results). In conclusion, the results of the present study do not seem to be inconsistent with the classification of PG1 and PG3 as representatives of two subspecies of the same species. The decision should obviously be based on theoretical considerations, but as it entails practical consequences, we prefer to leave the decision to the Subcommittee.

The classification of Y-goat as a strain of M. mycoides subsp. mycoides (Al-Aubaidi \& Fabricant 1971a) is confirmed by the serological results presented in this study. The nucleic acid homology between PG1 and Y-goat of $90 \%$, which is at the lower 
level for the accuracy of measurement of experiments between different DNA preparations of the same strain, is also in support of this classification. It should be emphasized that the serological grouping of goat strains into the same subspecies as the bovine strains which causes contagious bovine pleuropneumonia does not imply pathogenicity for cattle; the caprine group would in this case be specifically classified as M. mycoides subsp. mycoides pathovar. capri.

As regards the strains $\mathrm{PG50}$ and $\mathrm{B} 144 \mathrm{P}$, representing serogroups 7 of Leach and L of Al-Aubaidi and Fabricant, no crossreactions were found in metabolism-inhibition and immunofluorescence tests (Al-Aubaidi \& Fabricant 1971a,b). But oneway cross-reactions were demonstrated between these organisms in the metabolism-inhibition and growth-inhibition tests, and common antigens were shown by double immunodiffusion and growth precipitation (Ernф \& Jurmanová, Ernф et al. 1973). In this study, significant cross-reactions were demonstrated in growth inhibition and immunofluorescence, whereas only a oneway cross-reaction was shown in the metabolism-inhibition test. The close relationship demonstrated by serological methods is greatly supported by the very high level of hybridization (90\%), and it is therefore concluded that the strains be classified both in the same species and in the same subspecies.

As mentioned above, Cottew (1970) suggested that PG50 be a subdivision of M. bovigenitalium, while Ern $\varnothing$ \& Jurmanová tended to relate this strain to $M$. mycoides. In the present study, one-way cross-reactions were demonstrated between PG1 and PG50 antiserum in growth inhibition and immunofluorescence, and between PG50 and PG3 antiserum in growth inhibition, as one-way cross-reactions have previously been observed by the same methods between PG50 and strains of $M$. bovigenitalium (Cottew, Ern $\phi \&$ Jurmanová). However, the DNA homologies between PG50/B144P and PG1 and PG3 are on average 85/85 and $75 / 79$, indicating that $\mathrm{PG50}$ and $\mathrm{B} 144 \mathrm{P}$ are rather closely related to M. mycoides. The DNA homologies of $13 \%$ to $23 \%$ between strain $\mathrm{K}$ of $\mathrm{M}$. bovigenitalium and strains PG1, PG3, PG50 and $\mathrm{B} 144 \mathrm{P}$, respectively, demonstrate that strain $\mathrm{K}$ is so distantly related to the Mycoides group that PG50/B144P cannot be representatives of a subdivision of $\mathrm{M}$. bovigenitalium. It is therefore concluded that PG50/B144P represents either a third separate subspecies within M. mycoides or a new species. The de- 
cision of this question is very closely related to that which the Subcommittee may make as regards PG1 and PG3.

\section{ACKNOWLEDGEMENTS}

We thank Dr. Anders Holst Andersen and Mr. Bent Jørgensen, the Institute of Mathematics, University of Aarhus, for the statistical calculations.

\section{REFERENGES}

Al-Aubaidi, J. M. \& J. Fabricant: Characterization and classification of bovine mycoplasma. Cornell Vet. 1971a, 61, 490-518.

Al-Aubaidi, J. M. \& J. Fabricant: The practical application of immunofluorescence (agar block technic) for the identification of mycoplasma. Cornell Vet. 1971b, 61, 519-542.

Al-Aubaidi, J. M., A. H. Dardiri \& J. Fabricant: Biochemical characterization and antigenic relationship of Mycoplasma mycoides subsp. mycoides, Freundt and Mycoplasma mycoides subsp. capri (Edward) Freundt. Int. J. system. Bact. 1972, 22, 155-164.

Alling, D. W.: Tests of relatedness. Biometrika 1967, 54, 459-469.

Blom, E. \& H. Ern $\varnothing:$ Mycoplasmosis: Infections of the genital organs of bulls. Acta vet. scand. 1967, 8, 186-188.

Cottew, G. S.: Mycoplasmas isolated from cattle in Australia. Aust. vet. J. $1970,46,378-381$.

Cottew, G. S. \& L. C. Lloyd: An outbreak of pleurisy and pneumonia in goats in Australia attributed to a mycoplasma species. J. comp. Path. 1965, 75, 363-374.

Cottew, G. S., W. A. Watson, O. Erdag \& F. Arisoy: Mycoplasmas of caprine pleuropneumonia in Turkey and their relationship to other mycoplasmas of goats and M. mycoides var. mycoides. J. comp. Path. 1969, 79, 541-551.

Denhardt, D. T.: A membrane-filter technique for the detection of complementary DNA. Biochem. biophys. Res. Commun. 1966, 23, 641-646.

Edward, D. G. ff.: Organisms of the pleuropneumonia group causing disease in goats. Vet. Rec. 1953, 65, 873-875.

Ernф, H. \& K. Jurmanová: Bovine mycoplasmas: Serological studies by double immunodiffusion, growth precipitation and growth inhibition. Acta vet. scand. 1973, 14, 524-537.

Ernф, H., K. Jurmanová \& R. H. Leach: Bovine mycoplasmas: A serological study by the metabolic inhibition test. Acta vet. scand. 1973, 14, 511-523.

Freundt, E. A.: The classification of the pleuropneumonia group of organisms (Borrelomycetales). Int. Bull. bact. Nomencl. 1955, $5,67-78$.

Laws, L.: A pleuropneumonia-like organism causing peritonitis in goats. Aust. vet. J. 1956, 32, 326—329. 
Leach, R. H.: Further studies on classification of bovine strains of Mycoplasmatales with proposals for new species, Acholeplasma modicum and Mycoplasma alkalescens. J. gen. Microbiol. 1973, $75,135-153$.

Marmur, J.: A procedure for the isolation of deoxyribonucleic acid from microorganisms. J. molec. Biol. 1961, 3, 208-218.

Marmur, J. \& P. Doty: Determination of the base composition of deoxyribonucleic acid from its thermal denaturation temperature. J. molec. Biol. 1962, 5, 109-118.

Razin, S.: Mycoplasma taxonomy studied by electrophoresis of cell proteins. J. Bact. 1968, 96, 687-694.

Rosendal, S. \& F. T. Black: Direct and indirect immunofluorescence of unfixed and fixed mycoplasma colonies. Acta path. microbiol. scand. Section B. 1972, 80, 615-622.

Subcommittee on the Taxonomy of Mycoplasmatales: Minutes of the Meeting, 10 August 1970. Int. J. system Bact. 1971, 21, 151-153.

Subcommittee on the Taxonomy of Mycoplasmatales: Minutes of the Interim Meeting, 18 September 1974. Int. J. system. Bact. 1975, $25,237-239$.

\section{SAMMENDRAG}

Bovine mykoplasmer: Klassifikation af organismer relateret til Mycoplasma mycoides.

Mykoplasmer, der på forskellige måder har vist sig at være relaterede til Mycoplasma mycoides, er blevet unders $\varnothing$ gt med henblik på klassifikation og nomenklatur. Repræsentative stammer for $M$. mycoides - subspecies mycoides (PG1) og subspecies capri (PG3) - samt for de endnu ikke klassificerede bovine serogrupper 7 (PG50) og L (B144P), er blevet sammenholdt serologisk og ved DNA-DNA hybridisering. De anvendte serologiske metoder (metabolisme inhibition, væksthæmning og immunofluorescens) anses sædvanligvis for at være speciesspecifikke.

(1) De 2 underarter af M. mycoides kan klart adskilles ved alle 3 serologiske metoder, men hybridiseringsunders $\varnothing$ gelserne gav til resultat, at ligheden er stor, idet der fandtes en "relatedness value" på $\mathbf{0 , 7 0 .}$

(2) De 2 serogrupper ( 7 og L) krydsreagerede med hinanden ved alle 3 serologiske metoder, og der fandtes en "relatedness value" på 0,83. Der fandtes en "relatedness value" på 0,72 mellem gruppe 7 og M. mycoides subsp. mycoides, og der påvistes her nogen krydsreaktion ved immunofluorescens og væksthæmning.

(3) Gruppe $7 \mathrm{og} \mathrm{L}$ fandtes i ringe grad at være genetisk relateret til M. bovigenitalium, idet der fandtes en DNA-homologi på $20 \%$ og derunder. I serologisk henseende er der i tidligere arbejder ved væksthæmning påvist krydsreaktion mellem gruppe $7 \mathrm{og}$ M. bovigenitalium.

I henseende til konklusioner på grundlag af de foranstående præmisser kommer man $i$ et dilemma, idet der foreligger 3 forskellige situationer. Ved (1) fandtes signifikante serologiske forskelle, men DNA- 
homologien var stor. Ved serogrupperne 7 og $L$ (2) var der overensstemmelse mellem hybridisering og serologiske fund. I (3) var der klar adskillelse ved hybridisering; serologisk krydsreaktion er tidligere påvist. Vælger man at lade hybridiseringsresultaterne være afgørende, kan man bibeholde de 2 underarter af M. mycoides, men man kommer herved i modstrid med hovedreglen, at de benyttede serologiske metoder er speciesspecifikke. Vælger man at lade serologien være mest afgørende, bliver PG1 og PG3 at betragte som 2 selvstændige arter, og gruppe L/7 må som en konsekvens også blive en selvstændig art.

Med hensyn til relationen mellem sidstnævnte gruppe og M. bovigenitalium viser hybridiseringsresultaterne klart, at det drejer sig om 2 forskellige arter. Som en konsekvens heraf må man acceptere, at der kan være krydsreaktioner, også ved væksthæmning, mellem forskellige arter, der genetisk set står hinanden endog meget fjernt.

På grundlag af problemernes principielle natur foretrækker forfatterne at overlade afgørelserne - og dermed navngivningen - til The Subcommittee on the Taxonomy of Mycoplasmatales.

(Received October 27, 1977).

Reprints may be requested from: H. Ern $\varnothing$, the Institute of Medical Microbiology, University of Aarhus, DK-8000 Aarhus C, Denmark. 